\title{
Comparing the Effectiveness of Oral Immunotherapy and Epicutaneous Immunotherapy on the Desensitization of Peanut Allergies
}

\author{
Gunawardana Dulmi ${ }^{1}$, Alanna Harricharan ${ }^{2}$, Visnavi Jeyasegaran ${ }^{2}$, Florin Buhas ${ }^{1}$ and Moheem Halari ${ }^{3^{*}}$ \\ ${ }^{1}$ Department of Medicine, All Saints University, Hillsborough Street, Roseau, Dominica \\ ${ }^{2}$ Department of Medicine, All Saints University College of Medicine, Kingstown, Saint Vincent and the Grenadines \\ ${ }^{3}$ Department of Clinical Affairs (Academic), All Saints University School of Medicine, Hillsborough Street, Roseau, Dominica
}

*Corresponding author: Moheem Halari, Department of Clinical Affairs, Assistant Dean, All Saints University School of Medicine, Hillsborough Street, Roseau, Dominica, Telephone: 1866-602-9555; E-mail: assistantdean.acd@allsaintsuniversity.org

Received date: February 9, 2018; Accepted date: February 18, 2018; Published date: February 25, 2018

Copyright: ( $) 2018$ Gunawardana D, et al. This is an open-access article distributed under the terms of the Creative Commons Attribution License, which permits unrestricted use, distribution, and reproduction in any medium, provided the original author and source are credited.

\begin{abstract}
There is a continuous rise in peanut allergies commonly found in the younger generations, which has caused an increase in demand for preventative treatment as opposed to mere management. Currently, avoidance of the allergen is the usual recommendation for those with peanut allergies. Two peanut immunotherapies, oral immunotherapy (OIT) and epicutaneous immunotherapy (EPIT) aim to successfully desensitize individuals of the allergen. This review compiled subjects from various studies to see which methodology is most effective in the prevention of peanut allergies. A total of 122 active subjects for oral immunotherapy with a success rate of $71 \%(87)$ followed by 273 active subjects for epicutaneous immunotherapy with a success rate $56 \%$ (154). OIT and EPIT both differ in administration and technique; however, it is evident that OIT is the more effective treatment. Although further studies must be conducted to ensure the safety and efficiency of both OIT and EPIT; completed studies deem the immunotherapies propitious.
\end{abstract}

Keywords: Peanut allergy; Oral immunotherapy; Desensitization; Epicutaneous immunotherapy; Effectiveness; Systematic review; Chronic illness

\section{Introduction}

In the United States of America, the sixth leading cause of chronic illness is due to allergies [1]. An allergy is a response to allergens caused by the antibodies known as immunoglobulin E (IgE) [2]. The body overreacts to what it identifies as an allergen, consequently stimulating an increase in the production of IgE [2]. Immunoglobulin $\mathrm{E}$ then cause mast cells to release mediators resulting in Anaphylaxis, a severe allergic reaction [2,3]. Common symptoms of anaphylaxis include dermatologic and respiratory symptoms [4]. Immediate use of Epinephrine (adrenaline) reduces the episode of the reaction [4].

A common food allergy which has an increased prevalence in present day society is peanut allergy [5]. Currently, there are no definite treatment(s) for peanut allergies other than management by avoidance of peanuts [6]. This literature review is a systematic review with the intention to explore two main allergen-specific immunotherapies which may lead to the desensitization of peanut allergies, and supported by meta-analyses from various scholarly works. The two methods that were the focus of this discussion were: oral and epicutaneous immunotherapies on peanut allergy.

The purpose of immunotherapy is to "improve or restore immune system function" [7]. The objective of peanut immunotherapy, both in OIT and EPIT is to enable the immune system to respond to the peanut allergen without causing an allergic reaction [8]. In peanut oral immunotherapy, subjects are reintroduced to their allergen, peanut protein, orally in small doses [9]. Whereas, in epicutaneous immunotherapy, subjects wear a patch with initial doses of peanut protein that reintroduces the allergen through the skin [10]. Both immunotherapies aim to desensitize the subject's allergen, therefore allowing them to encounter the allergen without the immune system eliciting an autoimmune response [9].

Epicutaneous Immunotherapy was first introduced as a treatment for allergies in 1917 by Besredka, who showed that specific antibodies can be activated by EPIT In addition, the first successful case study of EPIT was reported in 1921 by Vallery-Radot, who discovered that allergen administration onto scarified skin reduced systemic allergic symptoms in patients allergic to horses [11-13].

The main objective of this piece is to compare and contrast oral and epicutaneous immunotherapy to identify which methodology is most effective in the desensitization of peanut allergies in patients.

\section{Methods}

This systematic review primarily used internet based resources. The main search engines that were utilized were: PubMed, Google Scholar, University of Toronto Libraries, The JAMA Network, BioMed Central and The Public Library of Science (PLOS).

This literary piece is an amalgamation of critically assessed works that primarily focus on desensitizing peanut allergies through immunotherapies; thus, it was essential to introduce parameters to this study. Considering the vast resources that were at hand, it was necessary to actively use parameters such as: age of the population, geography of the subjects assessed, time frame of when the studies were conducted, and if clinical trials were implemented on human subjects or animals.

Peanut allergy is a fairly common food allergy; however, there are limited clinical studies that have been conducted on these specific 
immunotherapies reflecting this allergen. If cohort studies have been done, the primary focus has been the use of oral and sublingual immunotherapy on patients, as opposed to the comparison of oral and epicutaneous immunotherapy on human subjects. Our scope of methodology was to gather as many articles and clinical studies done on the desensitization of peanut allergies through oral and epicutaneous immunotherapy. We facilitated this search through key terms such as: peanut allergy, epicutaneous immunotherapy, oral immunotherapy, and desensitization. We gathered 79 articles in relation to our topic. Moreover, through dissection and critically assessing these pieces, we were left with 12 articles with relation to oral and epicutaneous immunotherapies in desensitizing peanut allergies. Of the 43 articles that were gathered from oral immunotherapy, 37 were eliminated because the scope of study was more than 10 years. It was necessary to eliminate older studies because the procedures done in the past were not as effective or it simply had no relation to these types of immunotherapies. Furthermore, of the 36 articles that were directly correlated to epicutaneous immunotherapy, 30 were eliminated because the study was either conducted on mice, or the main allergen was cow's milk or pollen, as opposed to peanut allergy. Another reason for elimination pertained to geography, some studies focused on allergies in the United Kingdom, whereas our scope of interest was primarily within the United States. We eliminated a global study due to lack of evidence in many countries, however, the United States provided much more results for our review (Figure 1).

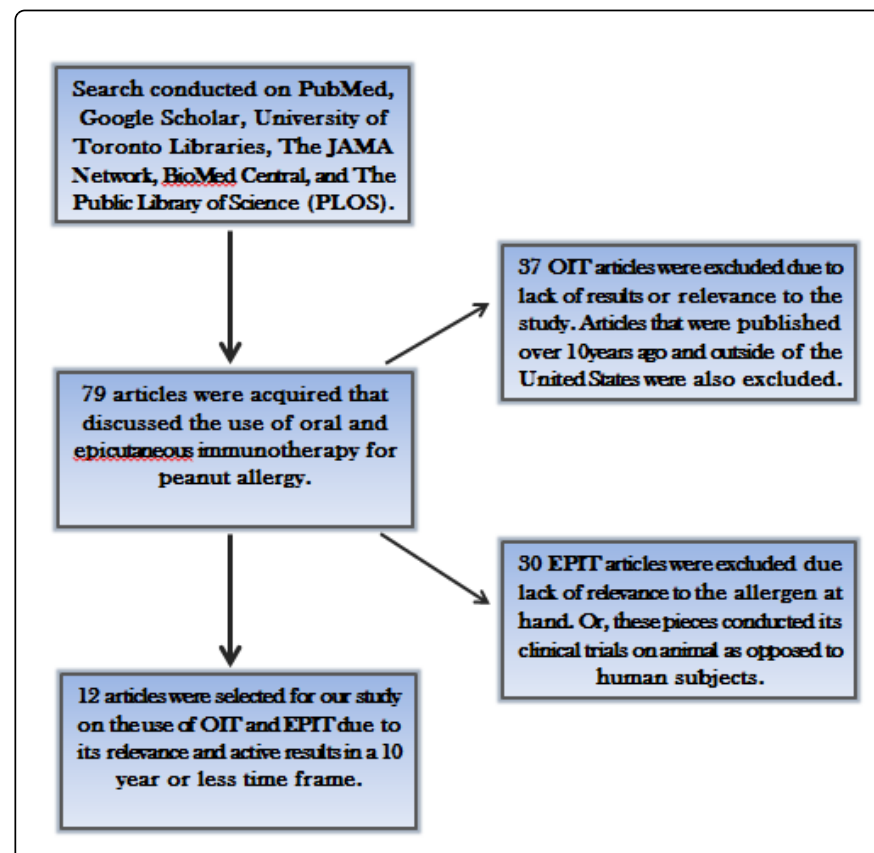

Figure 1: A flowchart which demonstrates our methodological approach of the initial number of articles identified; which we dissected and filtered out pertaining to its relevance to oral and epicutaneous immunotherapy on subjects with peanut allergies.

\section{Results}

These results are based on an amalgamation of meta-analyses taken from clinical trials regarding oral [14-19] and epicutaneous immunotherapy [20,21]. 188 subjects ages 1-26 underwent active oral immunotherapy for their peanut allergies. During the initial escalation phase, subjects ingested between 0.1-50 mg of peanut protein without experiencing any allergic symptoms. After the build-up and maintenance phases, 66 subjects withdrew from the study due to various reasons, such as: side effects, anxiety, and personal reasons. 122 active OIT subjects remained. These subjects successfully ingested a dosage of 500-5000 mg of peanut protein. On the other hand, relevant studies regarding epicutaneous immunotherapy successfully outlined pilot studies, sample groups, etc. A total of 295 subjects were selected to test the effectiveness of EPIT. Phase 1 of the study saw an attrition of 22 subjects, leaving 273 active participants. These subjects were randomized and chosen to conduct a double-blind clinical trial. The sample groups were given protein patches of $25-50 \mu \mathrm{g}$ in the initial phase to an increased end point of 500-1000 $\mu$ g. Of the remaining 273 subjects, 154 participants were successfully treated by EPIT (Table 1).

\begin{tabular}{|l|l|l|}
\hline & $\begin{array}{l}\text { Oral } \\
\text { Immunotherapy }\end{array}$ & $\begin{array}{l}\text { Epicutaneous } \\
\text { Immunotherapy }\end{array}$ \\
\hline $\begin{array}{l}\text { Total Number of } \\
\text { Subjects (n) }\end{array}$ & 188 & 295 \\
\hline Age (years) & $1-26$ & $4-55$ \\
\hline Initial Rush Dosage & $0.1-50 \mathrm{mg}$ & $25-50 \mu \mathrm{g}$ \\
\hline $\begin{array}{l}\text { No. of Active Subjects } \\
\text { at the End of the } \\
\text { Study } \\
\text { (After Withdrawals) }\end{array}$ & 122 & 273 \\
\hline $\begin{array}{l}\text { Final Maintenance } \\
\text { Dosage }\end{array}$ & $500-5000 \mathrm{mg}$ & $500-1000 \mu \mathrm{g}$ \\
\hline $\begin{array}{l}\text { No. of Subjects with } \\
\text { Successful OIT and } \\
\text { EPIT Immunotherapy } \\
\text { Results }\end{array}$ & $87(71 \%)$ & $154(56 \%)$ \\
\hline
\end{tabular}

Table 1: Comparative Clinical Trials for OIT and EPIT.

Previous studies using commercial peanut products have suggested that oral immunotherapy is a suitable approach to treating peanut allergy [22]. OIT has been studied for more than a decade in clinical trials and has the largest body of evidence among emerging therapies for food allergy [23]. With all of these studies, oral immunotherapy has the largest effect on desensitization than the other well-known immunotherapy, epicutaneous therapy (EPIT). Current OIT protocols typically include 3 phases requiring ingestion of allergen-specific flour in a food vehicle: (1) modified rush desensitization (initial escalation) with 6 to 8 doses of allergen given rapidly during day 1; (2) build-up dosing under observation every 1 to 2 weeks until a target dose is reached (over 6-12 months); and (3) daily home maintenance dosing (typically years) [23]. Even though OIT seems to be more of an approachable way to treat peanut allergy, there are limitations caused by safety issues. The presumed mechanism of action for OIT is activation of gut mucosal dendritic cells, which affect the allergic response through immunomodulation of tissue and circulating effector cells [24]. There were ongoing side effects as the treatment was conducted, some were mild and moderate. There were also gastrointestinal side effects, including abdominal pain, cramping, nausea and vomiting, that occurred in $10 \%$ to $20 \%$ of subjects receiving OIT, which ultimately led to the discontinuation of therapy [25].

Although OIT has demonstrated clinical efficacy for desensitization, meta-analyses highlight the fact that insufficient data exist for full 
efficacy assessments and that safety concerns persist and require further evaluation $[22,23,26,27]$.

Epicutaneous Immunotherapy (EPIT) involves the application of an allergen-containing patch to the skin surface [23]. EPIT uses a novel delivery of allergen to the skin surface through application of an allergen-containing patch to activate skin Langerhans cells, with subsequent migration to lymph nodes and down regulation of effector cell responses [28]. Although there was a larger population within this study for EPIT, the protein patches administered were in microgram as opposed to milligrams in the OIT treatments. This illustrates that subjects were more susceptible to increasing doses of peanut protein through oral treatment in comparison to epicutaneous.

In both of these studies, severe reactions were extremely rare, which suggest that both forms of immunotherapy are safe and effective for the population. In EPIT studies, most of the patients were having mild and moderate side effects compared to OIT [29]. However, in both studies, there was a small percentage where patients discontinued the treatment, which further supports the effectiveness of the results that were gathered $[22,23,26,27]$. It is necessary to note that majority of the prospective clinical trials used for the meta-analysis of this study conducted these trials within the same time frame of 52 weeks or 12 months. Moreover, the EPIT studies were randomized, as well as double-blind, thus, eliminating bias [30-33].

\section{Conclusion}

In many studies it has been proven that both oral immunotherapy and epicutaneous immunotherapy are able to desensitize peanut allergen patients effectively. In oral immunotherapy studies, the response from the patients is extremely favorable with most of patients having no side effects. There were only $10 \%$ to $20 \%$ that experienced gastrointestinal side effects, for which a few patients had to discontinue the treatment. In EPIT studies, the treatment was also effective but not to the degree of OIT, and $90 \%$ of the patients had mild or moderate side effects, which also caused some patients to withdraw from the treatment. From this review we conclude that Oral immunotherapy is the superior treatment and methodological approach for desensitizing peanut allergy, which is evident in the results, with very few patients suffering from side effects or withdrawing from the trial. Furthermore, most of the patients that had received the treatment were successfully desensitized.

\section{References}

1. https://www.cdc.gov/healthcommunication/index.html

2. Laura JM (2016) Allergic Reaction|AAAAI. The American Academy of Allergy, Asthma \& Immunology.

3. Valent P, Akin C, Arock M, Brockow K, Butterfield JH, et al. (2012) Definitions, criteria and global classifications of mast cell disorders with special reference to mast cell activation syndromes: a consensus proposal. Int Arch Allergy Immunol 157: 215-225.

4. Arnold JJ, Williams PM (2011) Anaphylaxis: Recognition and management. Am Fam Physician 84: 1111-1118.

5. Foong RX, Brough H (2017) The role of environmental exposure to peanut in the development of clinical allergy to peanut. Clin Exp Allergy 47: $1232-1238$.

6. Boyce J, Assa'ad A, Burks AW, Jones SM, Sampson HA, et al. (2011) Guidelines for the diagnosis and management of food allergy in the United States: summary of the NIAID-sponsored expert panel report. Allergy Clin Immunol 126: 58.

7. ASCO (2017) Understanding Immunotherapy. Cancer Net.
8. Caruso D, Ashley D (2002) Overview. Cancer Forum.

9. Bajowala, Sakina (2017) Oral Immunotherapy. Kaneland Allergy \& Asthma Center.

10. Hillary Hoffman (2016) Skin Patch to Treat Peanut Allergy Shows Benefit in Children. National Institutes of Health, U.S Department of Health and Human Services.

11. Blamoutier P, Blamoutier J, Guibert L (1959) Traitement co-saisonnier de la pollinose par l'application d'extraits de pollens sur des quadrillages cutanés: Résultats obtenus en 1959 et 1960. Rev Fr d'Allergie 1: 112-120.

12. Vallery-Radot P, Hangenau J (1921) Asthme d’origine équine. Essai de désensibilisation par des cutiréactions répétées. Bull Soc Méd Hôp Paris 45: 1251-1260.

13. Senti G, Von Moos S, Kündig TM (2014) Epicutaneous Immunotherapy for Aeroallergen and Food Allergy. Curr Treat Options Allergy 1: 68-78.

14. Kukkonen AK, Uotila R, Malmberg LP, Pelkonen AS, Mäkelä MJ (2017) Double-blind placebo-controlled challenge showed that peanut oral immunotherapy was effective for severe allergy without negative effects on airway inflammation. Acta Paediatr 106: 274-281.

15. Vickery BP, Scurlock AM, Kulis M, Steele PH, Kamilaris J, et al. (2014) Sustained Unresponsiveness to Peanut in Subjects Who Have Completed Peanut Oral Immunotherapy. J Allergy Clin Immunol 133: 468-475.

16. Bird JA, Spergel JM, Jones SM , Rachid R, Assa'ad AH, et al. (2017) Efficacy and Safety of AR101 in Oral Immunotherapy for Peanut Allergy: Results of ARC001, a Randomized, Double-Blind, Placebo-Controlled Phase 2 Clinical Trial. J Allergy Clin Immunol Pract 17: 2213-2198.

17. Blumchen K, Ulbricht H, Staden U, Dobberstein K, Beschorner J, et al. (2010) Oral peanut immunotherapy in children with peanut anaphylaxis. J Allergy Clin Immunol 126: 83-91.

18. Varshney P, Jones SM, Scurlock AM, Perry TT, Kemper A, et al. (2011) A Randomized Controlled Study of Peanut Oral Immunotherapy (OIT): Clinical Desensitization and Modulation of the Allergic Response. J Allergy Clin Immunol 127: 654-660.

19. Jones SM, Pons L, Roberts JL, Scurlock AM, Perry TT, et al. (2017) Clinical Efficacy and Immune Regulation With Peanut Oral Immunotherapy. J Allergy Clin Immunol 124: 292-300.

20. Jones SM, Sicherer SH, Burks AW, Leung DY, Lindblad RW, et al. (2017) Epicutaneous immunotherapy for the treatment of peanut allergy in children and young adults. J Allergy Clin Immunol 139: 1242-1252.

21. Sampson HA, Shreffler WG, Yang WH, Sussman GL, Brown-Whitehorn TF, et al. (2017) Effect of Varying Doses of Epicutaneous Immunotherapy vs Placebo on Reaction to Peanut Protein Exposure Among Patients With Peanut Sensitivity. JAMA 318: 1798-1809.

22. Bird JA, Spergel JM, Jones SM, Rachid R, Assa'ad, et al. (2017) Efficacy and Safety of AR101 in Oral Immunotherapy for Peanut Allergy: Results of ARC001, a Randomized, Double-Blind, Placebo-Controlled Phase 2 Clinical Trial. J Allergy Clin Immunol Prac 17: 2213-2198.

23. Jones SM, Burks AW, Dupont C (2014) State of the Art on Food Allergen Immunotherapy: Oral, Sublingual, and Epicutaneous. J Allergy Clin Immunol 133: 318-323.

24. Vickery BP, Scurlock AM, Jones SM, Burks AW (2011) Mechanisms of immune tolerance relevant to food allergy. J Allergy Clin Immunol 127: 576-586.

25. Vickery BP, Scurlock AM, Steele P, Kamilaris J, Hiegel AM, et al. (2011) Early and persistent gastrointestinal side effects predict withdrawal from peanut oral immunotherapy (OIT) J Allergy Clin Immunol 127: AB26.

26. Song TW (2016) A practical view of immunotherapy for food allergy. Korean J Pediatr 59: 47-53.

27. Narisety SD, Keet CA (2012) Sublingual vs Oral Immunotherapy for Food Allergy: Identifying the Right Approach. Drugs 72: 1977-1989.

28. Novak N, Gros E, Bieber T, Allam JP (2010) Human skin and oral mucosal dendritic cells as 'good guys' and 'bad guys' in allergic immune responses. Clin Exp Immunol 161: 28-33.

29. Agbotounoi W, Martin L, Dupont D, Pascal I, Vauleon C, et al. (2013) Epicutaneous immunotherapy (EPIT) is safe for the treatment of peanut allergy in allergic patients. J Allergy Clin Immunol 131: AB91. 
Citation: Dulmi G, Harricharan A, Jeyasegaran V, Buhas F, Halari M (2018) Comparing the Effectiveness of Oral Immunotherapy and Epicutaneous Immunotherapy on the Desensitization of Peanut Allergies . J Allergy Ther 9: 272. doi:10.4172/2155-6121.1000272

Page 4 of 4

30. Sampson HA, Shreffler WG, Yang WH, Sussman GL, Brown-Whitehorn TF, et al. (2017) Effect of Varying Doses of Epicutaneous Immunotherapy vs Placebo on Reaction to Peanut Protein Exposure Among Patients With Peanut Sensitivity: A Randomized Clinical Trial. JAMA 318: 1798-1809.

31. Jones SM, Sicherer SH, Burks AW, Leung DY, Lindblad RW, et al. (2016) Epicutaneous immunotherapy for the treatment of peanut allergy in children and young adults. J Allergy Clin Immunol 139: 1242-1252.
32. Stacie MJ, Scott HS, Wesley BA, Donald YM, Robert WL, et al. (2017) Epicutaneous immunotherapy for the treatment of peanut allergy in children and young adults. J Allergy Clin Immunol 139: 1242-1252.

33. Agbotounoi W, Martin L, Dupont D, Pascal I, Vauleon C, et al. (2012) Epicutaneous immunotherapy (EPIT) is safe for the treatment of peanut allergy in allergic patients. J Allergy Clin Immunol 131: AB91. 